\title{
Habitat heterogeneity and anuran community of an agroecosystem in the Pantanal of Brazil
}

\author{
Franco Leandro Souza ${ }^{1}$, Fernando Ibanez Martins ${ }^{1}$, and Josué Raizer ${ }^{2}$ \\ ${ }^{1}$ Universidade Federal de Mato Grosso do Sul, Centro de Ciências Biológicas e da Saúde, 79070-900, Campo Grande, MS, \\ Brazil. E-mail: franco.souza@ufms.br. \\ 2 Universidade Federal da Grande Dourados, Faculdade de Ciências Biológicas e Ambientais, 79825-070, Dourados, MS, \\ Brazil.
}

\begin{abstract}
Habitat heterogeneity and anuran community of an agroecosystem in Pantanal, Brazil. The Pantanal of central Brazil has experienced considerable modifications as a result of growing land use. The association between anuran assemblage and the local habitat structure of an agroecosystem in central Brazil at the Pantanal is described. It is shown that the structure of the anuran community is reestablished within the new environmental dynamics in such human-modified habitat. Twenty-four anuran species were recorded in the area. The community was dominated by four species (Dendropsophus nanus, Leptodactylus chaquensis, Hypsiboas raniceps, and Rhinella cf. bergi), which accounted for more than $50 \%$ of the sampled individuals. The species distribution pattern was adjusted to the logarithmic, log-normal, and broken stick models, partially reflecting its association with agroecosystem characteristics. Habitat heterogeneity contributes to the anuran community at a local scale, thereby emphasizing the importance of maintaining distinct habitats for anuran species in the Pantanal as a management practice, even in in situations in which anthropic actions are predictable, as in agroecosystems.
\end{abstract}

Keywords: agriculture, amphibians, habitat complexity, Pantanal, wetland.

\begin{abstract}
Resumo
Heterogeneidade ambiental e comunidade de anuros em agroecossistema na região do Pantanal, Brasil. A planície pantaneira no Brasil Central tem sofrido intensa modificação devido às práticas de ocupação antrópica ocorrida nos últimos anos na região. Este trabalho ilustra a associação entre a comunidade de anfíbios anuros e a estrutura ambiental em escala local de um agroecossistema no Pantanal (Mato Grosso do Sul) e mostra que em ambientes modificados pela ação humana a comunidade de anuros pode ser restabelecida de acordo com as novas condições encontradas. Foram encontradas 24 espécies de anuros das quais quatro foram predominantes (Dendropsophus nanus, Leptodactylus chaquensis, Hypsiboas raniceps e Rhinella cf. bergi), representando mais de $50 \%$ dos
\end{abstract}

Received 19 September 2013.

Accepted 26 May 2014.

Distributed August 2014. 
indivíduos amostrados. O padrão de distribuição das espécies foi melhor ajustado aos modelos logarítmicos, log-normal e broken stick, refletindo parcialmente uma associação com as características do agroecossistema. A heterogeneidade ambiental contribuiu com a estrutura da comunidade, o que reforça a importância da manutenção de ambientes distintos para as espécies de anuros do Pantanal como uma prática de manejo mesmo em situações em que as ações antrópicas forem previsíveis e irreversíveis como os agroecossistemas.

Palavras-chave: agricultura, anfíbios, complexidade ambiental, Pantanal, planície de inundação.

\section{Introduction}

Although 946 amphibian species are recorded from Brazil (Segalla et al. 2012), there is much to be learned about the ecological factors that shape anuran community structure. Community ecology theory predicts that heterogeneous habitats will have higher species richness than homogeneous habitats at local and regional scales (Tews et al. 2004). A well-documented relationship between habitat complexity and species richness is documented for many species, including amphibians (Purrenhage and Bone 2009, Vasconcelos et al. 2009, Silva et al. 2011).

Agriculture is among the main causes of global loss of biodiversity resulting from expansion of croplands and pastures, as well as land-management practices involving irrigation and the use of fertilizers and pesticides (Foley et al. 2011). However, some species seem adapted to living in the marginal transitional zones between agro- and natural ecosystems (Altieri 1999). Several studies of the effects of agroecosystems on biodiversity have appeared in the last decade (Zamora et al. 2007, Duré et al. 2008, Piatti et al. 2010, Piatti and Souza 2011). It has become clear that it is important to distinguish the impacts of agricultural practices as opposed to natural processes on habitats over limited temporal and spatial scales (Benton et al. 2003, Hill and Hamer 2004, Jepsen et al. 2005). In this way, demographic responses to habitat changes can be associated with the ways in which species deal with the matrix permeability around natural habitats; depending upon the characteristics of the agroecosystem, the matrix may create severe barriers that affect population dynamics (Ricketts 2001, Benton et al. 2003, Weibull et al. 2003). In amphibians, there usually is a negative relationship between species diversity and agroecosystems, because the structure of the habitat can influence amphibian distributions along a heterogeneity gradient (Joly et al. 2001, Beja and Alcazar 2003, Piha et al. 2007). Given their physiological constraints, anuran activities are mediated by favorable microhabitat conditions, such as humidity and shelter (Eterovick and Ferreira 2008, Wachlevski et al. 2008, Vasconcelos et al. 2009, Silva et al. 2011).

In recent decades, the areas adjacent to the Pantanal in central Brazil have been modified by intensified land usage (Harris et al. 2006, Dobrovolski et al. 2011) that threatens their natural biodiversity. Wetlands throughout the world, including the Pantanal, are diminishing owing to agriculture. Natural wetlands are being functionally replaced by irrigated fields, which harbor many aquatic species, including amphibians (Duré et al. 2008, Machado and Maltchik 2010, Piatti et al. 2010, Piatti and Souza 2011); however, drainage activities and land management of these aquatic systems are thought to be harmful to anurans (Colombo et al. 2008). Thus, any information about the relationship between anuran populations and habitat complexity is strategically important to sound environmental management practice, especially in regions with 
high deforestation activities. Herein, we describe the association of an anuran assemblage with local habitat structure in an agroecosystem in the Pantanal and and demonstrate that even in such a human-dominated habitat, the structure of an anuran community can be remodeled in harmony with environmental characteristics that are anthropogenically modified.

\section{Materials and Methods}

With about 140,000 sq $\mathrm{km}$ of low-lying floodplains, the Pantanal is one of the largest wetlands in the world and hosts a rich biodiversity
(Junk et al. 2006, Alho 2011). This study was conducted in a farmland area dedicated to irrigated rice production (Fazenda San Francisco; municipality of Miranda, State of Mato Grosso do Sul, central Brazil; 2005'10" S, 56³6'57" W) located along the southeastern border of the Pantanal (Figure 1). The climate is tropical, and hot and wet (PCBAP 1997), with a well-defined rainy season from October-March and a dry season from April-September. The rice plantation occupies 3,400 ha of a total of 14,000 ha that also includes pastures and native vegetation; the later includes gallery and deciduous forests, as well as distinct cerrado physiognomies. The

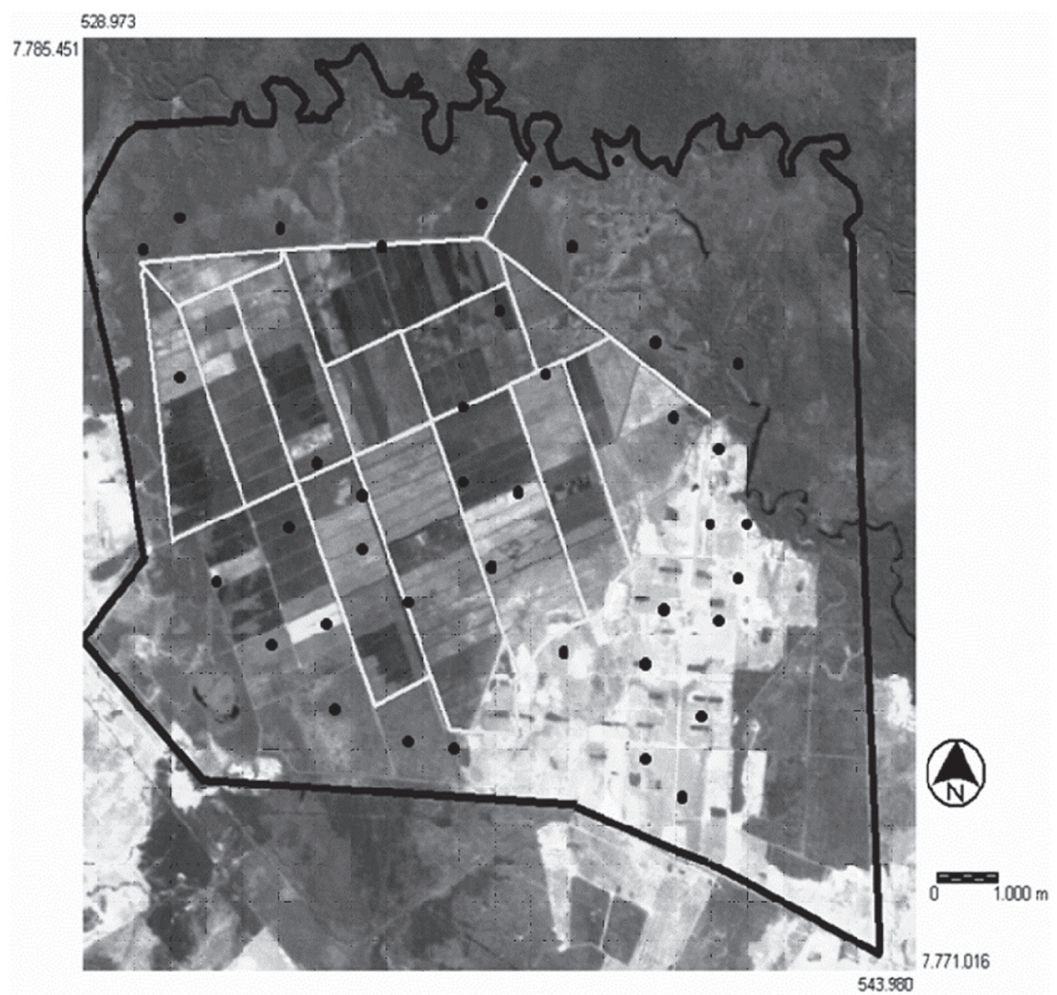

Figure 1. The Fazenda San Francisco is located at the south-eastern border of the Pantanal. Sinuous line at north indicates the Miranda River, which defines the natural limit of the area. The well-defined rectangles at center correspond to rice fields. Light areas correspond to pastures and dead vegetation while forest areas are gray. The white lines correspond to rice fields maintenance roads. Dots illustrate the location of the 40 sampled units. 
rice plantation is composed of several 40 ha quadrats $(200 \times 2000 \mathrm{~m})$ interconnected by local roads and drainage channels $(2-10 \mathrm{~m}$ wide and 0.5-1.5 m deep), which are supplied with water by the Rio Miranda (Piatti et al. 2010, Piatti and Souza 2011). Aquatic vegetation, herbaceous plants, and small trees grow along the banks of the drainage channels (Figure 1).

Sampling was carried out monthly during both the dry and the rainy seasons from April 2007-March 2008. Anurans and habitat heterogeneity were surveyed in 40 randomly sampled quadrats $(50 \times 50 \mathrm{~m}$; as described by Krebs 1999 ) in the farm area (Figure 1). Quadrats were separated by a minimum of $500 \mathrm{~m}$ to avoid spatial pseudo-replication. Two researchers actively searched (Heyer et al. 1994) each quadrat from 10:00-16:00 $\mathrm{h}$ and from 18:00 23:00 $\mathrm{h}$ to sample diurnal and nocturnal species. All the specimens found below a height of $4 \mathrm{~m}$ on the vegetation were captured, identified, and kept in plastic bags until quadrat sampling was completed. Captured individuals were released at least $1 \mathrm{~km}$ away from the sampled quadrats to avoid pseudo-replication and the consequent overestimation of the frequencies of the species (Piatti et al. 2010). Voucher specimens were euthanized with xylocaine, fixed in 5\% formalin, and transferred to $70 \%$ alcohol. Specimens were deposited at the Coleção Zoológica de Referência of the Universidade Federal de Mato Grosso do Sul (ZUFMS, Campo Grande, Mato Grosso do Sul State; voucher numbers: AMP00967, AMP01079-01081, AMP01083, AMP01087, AMP01089, AMP01097-01098, AMP01106-01108, AMP01110, AMP01124-01126, AMP0113201134, AMP01136, AMP01139, AMP01146). Collecting activities were permitted by ICMBio process number 10379 .

The predicted species richness for the area was assessed by sampled-based rarefaction curves for the 40 quadrats with EstimateS 8.0 (Colwell 2009) with 1000 randomizations of the original field samples employing the nonparametric Jackknife 1 index. The species abundance distribution pattern was assessed with a
Chi-square test on the geometric, logarithmic, log-normal, and broken stick abundance distribution models to check for the better adjustment to the observational data (Magurran 2004) with Bio-Dap (Thomas and Clay 2000).

Twenty-five $10 \times 10$-m grids were established for each of the 40 sampled quadrats; five quadrats were randomly chosen to assess habitat heterogeneity variables that included pasture field, rice field, naked soil, dead vegetation (shrubs and fallen trees), understory vegetation (shrubs and vines), litter, water cover, and aquatic vegetation. The relationship between anurans and these habitat characteristics was tested using a Canonical Correspondence Analysis, CCA (Ter Braak 1986); this multivariate approach associates species assemblage (dependent variable) with habitat characteristics (independent variables) throughout the respective data matrices. In this analysis, the association between habitat characteristics and abundance of particular anuran species was predicted. In the CCA, each quadrat sampled included measures for habitat characteristics, whereas the species matrix consisted of the number of individuals (Vitt et al. 2007). The CCA analysis was performed using the software PAST (Hammer et al. 2001) based on a Monte Carlo test with 1000 permutations.

\section{Results}

A total of 1721 individuals representing 24 anuran species of five families were recorded from the 40 sample quadrats of Fazenda San Francisco, as follow: Bufonidae: Rhinella cf. bergi and $R$. schneideri; Hylidae: Dendropsophus nanus, Hypsiboas punctatus, H. raniceps, Phyllomedusa azurea, P. sauvagii, Pseudis limellum, P. platensis, Scinax acuminatus, $S$. nasicus, and Trachycephalus typhonius; Leiuperidae: Eupemphix nattereri, Physalaemus albonotatus, $P$. centralis, $P$. cuvieri, and Pseudopaludicola sp.; Leptodactylidae: Leptodactylus chaquensis, L. diptyx, L. elenae, L. fuscus, and L. podicipinus; Microhylidae: Dermatonotus muelleri and Elachistocleis bicolor. 
Rarefaction curves suggested the occurrence of 24 anuran species in the area, with the tendency to reach the asymptote after sampling 10 quadrats (Figure 2). The community was dominated by four anuran species (Dendrosophus nanus, Hypsiboas raniceps, Leptodactylus chaquensis, and Rhinella cf bergi) representing more than $50 \%$ sampled individuals, whereas species such as Physalaemus cuvieri and Dermatonotus muelleri were less abundant (Figure 3). The species abundance distribution pattern was adjusted to all except the geometric model (Table 1).

According to the CCA analyses, there is a significant association between agroecosystem habitat structure and anuran community (eigenvalue $=0.329, \mathrm{P}<0.01$ ). Pseudis platensis, $P$. limellum, Dendrosophus nanus, and Leptodactylus fuscus were associated with aquatic habitats and aquatic vegetation; Elachistocleis bicolor, Phyllomedusa azurea, and $P$. sauvagii were associated with pastures and shrubs; Leptodactylus podicipinus, Pseudopaludicola sp., and both species of Rhinella were associated with rice fields. Physalaemus albonotatus, Leptodactylus diptyx, Eupemphix nattereri, Trachycephalus typhonius, Scinax nasicus, Hypsiboas punctatus, and $H$. raniceps were associated with areas dominated by forests characterized by abundant litter; Leptodactylus elenae was found in areas with dead vegetation and naked soil, whereas Leptodactylus cha-

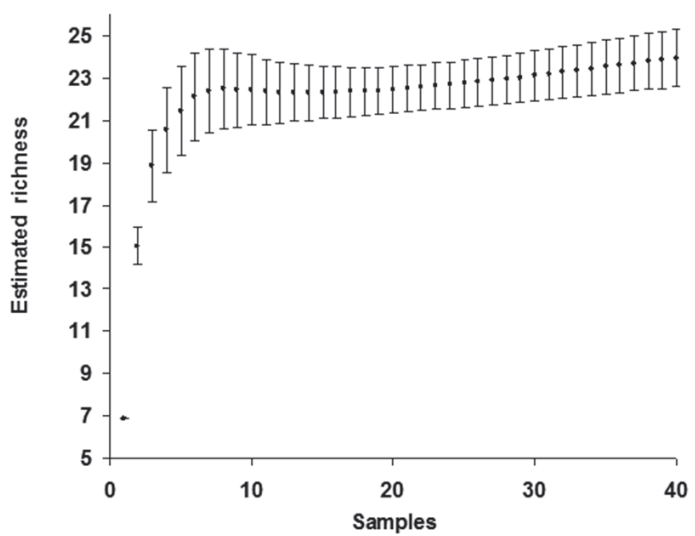

Figure 2. Rarefaction curve for anurans from the Fazenda San Francisco, Mato Grosso do Sul State, Central Brazil. The curve represents mean richness (bars denote standard deviations) estimated by Jackknife 1 method after 1,000 randomizations of the 40 sample units verified from April 2007 to March 2008.

quensis and Scinax acuminatus were associated in transitional areas with water and shrub vegetation (Figure 4).

\section{Discussion}

The 24 species of the anuran assemblage from Fazenda San Francisco represent approximately $40 \%$ of the anuran community associated with the Pantanal floodplains and

Table 1. Chi-square adjust analyses for the species abundance distribution models considered for the anuran community from Fazenda San Francisco agroecosystem, Mato Grosso do Sul State, Central Brazil. A P value $<0.05$ refers to significant difference between the observed and the expected species abundance distribution model.

\begin{tabular}{lccc}
\hline Models & Degrees of freedom & Chi-square & $\boldsymbol{P}$ \\
\hline Geometric & 21 & 275.4 & $<0.05$ \\
Logarithmic & 21 & 20.8 & $>0.05$ \\
Log-normal & 21 & 2.95 & $>0.05$ \\
Broken stick & 21 & 2.05 & $>0.05$ \\
\hline
\end{tabular}




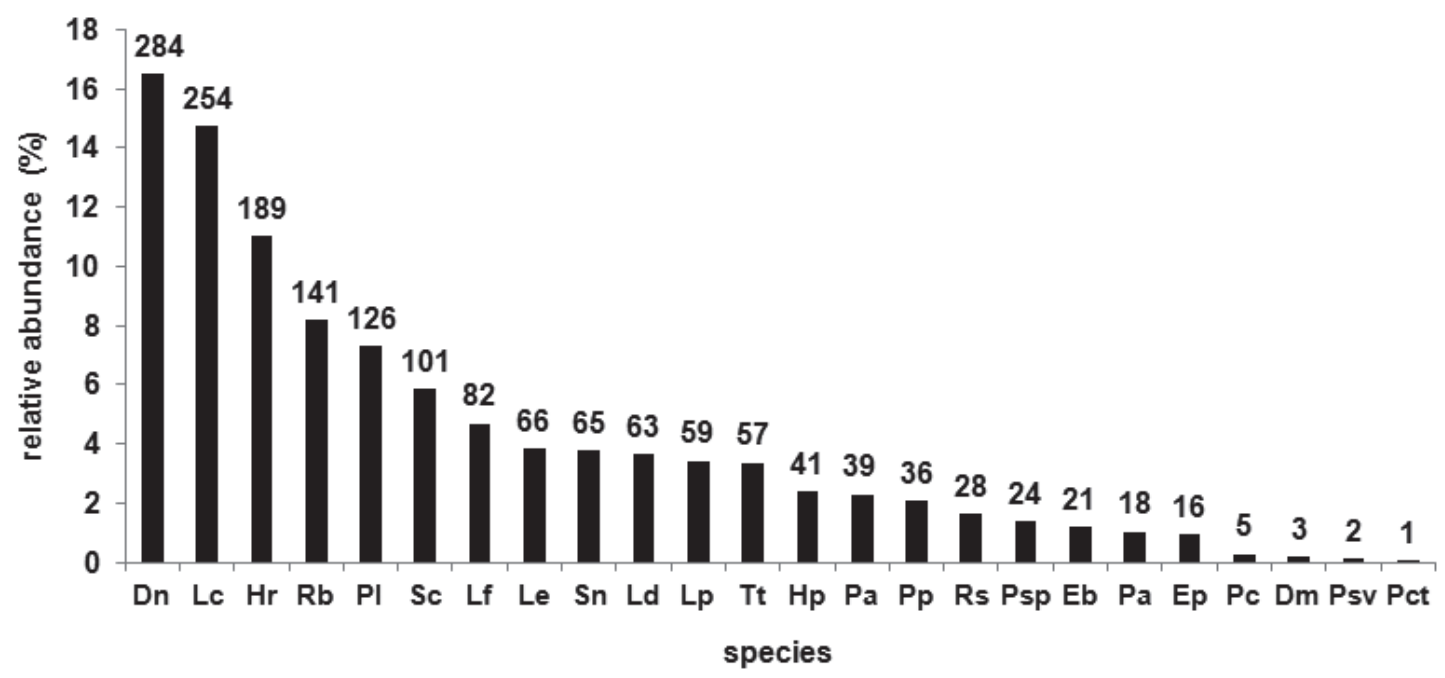

Figure 3. Relative abundance of the 24 anuran species sampled between April 2007 and March 2008 from Fazenda San Francisco, Mato Grosso do Sul State, Central Brazil. Values above bars indicate the number of individuals sampled for each species (Dn: Dendropsophus nanus; Lc: Leptodactylus chaquensis; Hr: Hypsiboas raniceps; Rb: Rhinella cf bergi; PI: Pseudis limellum; Sc: Scinax acuminatus; Lf: Leptodactylus fuscus; Le: Leptodactylus elenae; Sn: Scinax nasicus; Ld: Leptodactylus diptyx; Lp: Leptodactylus podicipinus; Tt: Trachycephalus typhonius; Hp: Hypsiboas punctatus; Pa: Physalaemus albonotatus; Pp: Pseudis platensis; Rs: Rhinella schneideri; Psp: Pseudopaludicola sp.; Eb: Elachistocleis bicolor; Pa: Phyllomedusa azurea; Ep: Eupemphix nattereri; Pc: Physalaemus cuvieri; Dm: Dermatonotus muelleri; Psv: Phyllomedusa sauvagii; Pct: Physalaemus centralis.

neighboring areas (Souza et al. in press). Although most of the recorded species might be considered habitat generalists (e.g., Rhinella schneideri, Dendropsophus nanus, Hypsiboas raniceps; see Uetanabaro et al. 2008), the habitat heterogeneity gradient in the area studied seems to influence the anuran community even in an anthropic-dominated habitat.

The distribution pattern of species abundance in the quadrats was adjusted to the logarithmic, log-normal, and broken-stick abundance distribution models. The log-normal and broken-stick models are characterized by a homogeneous distribution of species abundance whereas the logarithmic model is associated with a community dominated by few common species and a great diversity of rare species (Magurran 2004). Interspecific competition is thought to reflect affect a geometric series abundance distribution model by limiting or excluding niche overlap (Magurran 2004). However, this prediction is not usually apparent in open-area anuran communities, such as those that occur in agroecosystems, which usually are characterized by high temporal and spatial niche overlap (Duré et al. 2008, Santos et al. 2008, Piatti et al. 2010). In contrast, the log-normal distribution model, which describes a more equitable representation of species, is found in most of the communities in which assemblages are dominated by many ecological factors other than competition and resource availability. The logarithmic model 


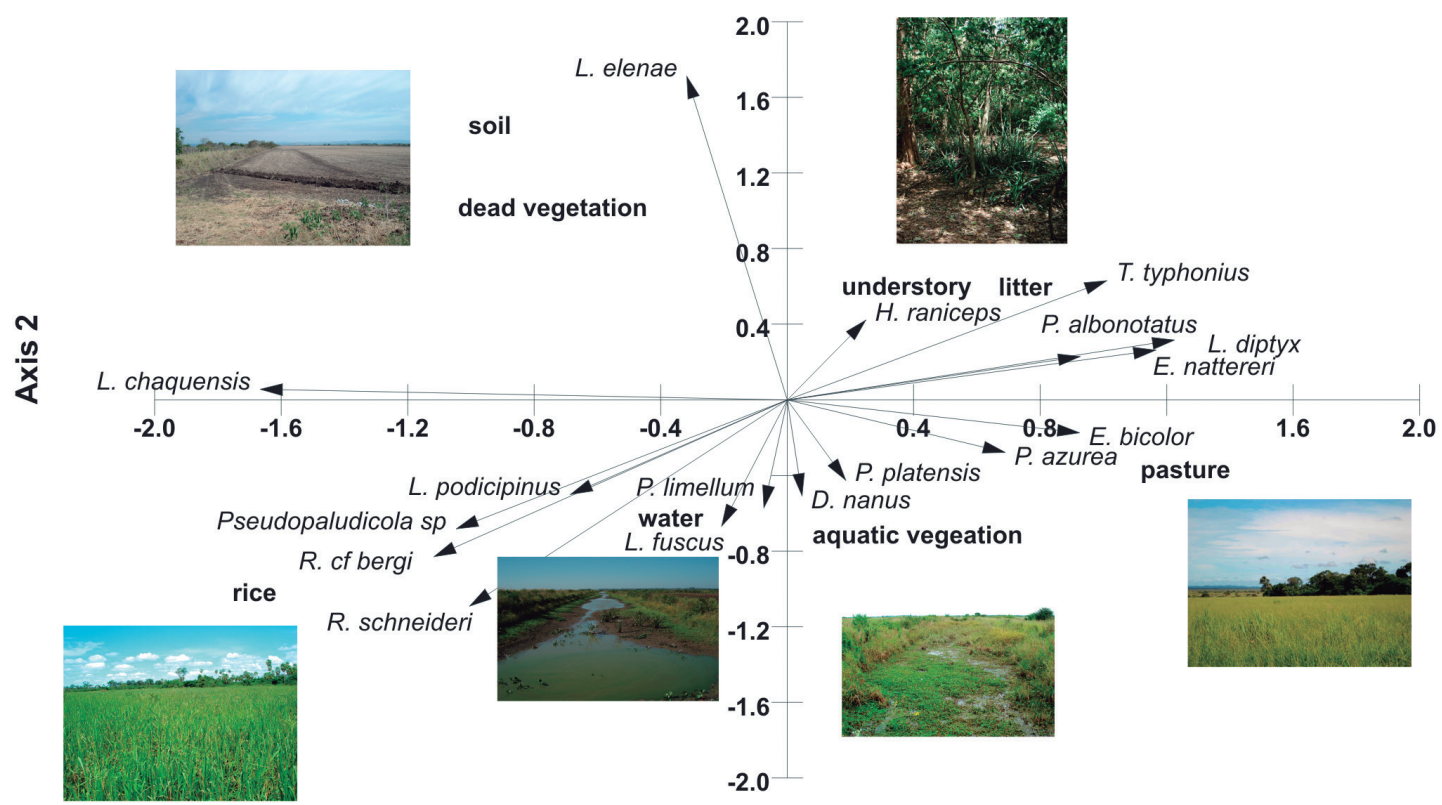

Axis 1

Figure 4. Association between habitat characteristics and anuran abundance matrices from Fazenda San Francisco, Mato Grosso do Sul State, Central Brazil, represented by a Canonical Correspondence Analysis. The plot shows the position of each anuran species among clusters on first two canonical axes. The arrows represent the direction of maximum change of the variable across the diagram and the length of the arrow is proportional to the rate of change. The position of the species in relation to the arrows indicates the environmental preference (illustrated by the photographs).

characterizes communities influenced by few factors and many uncommon species (Magurran 2004). Some species recorded here are classified as open-area dwellers that benefit from anthropic habitats edges, thereby partially reflecting the agroecosystem characteristics and the consequent distribution model fit. Separated analyses of local communities from habitats with distinct heterogeneity gradients, including rice fields, pastures, and forests patches, may generate interesting information about ecological interactions among species inhabiting this agroecosystem.

Habitat heterogeneity in agroecosystems can influence anuran community structure in agricultural landscapes (Guerry and Hunter 2002,
Gardner et al. 2007, Silva et al. 2011), even though fundamental structures, such as fallen trees and burrows, can contribute in a more predictive way at local scales (Tews et al. 2004). The habitat variables representing the habitat heterogeneity selected in this study seem to affect the anuran community at a local scale. Species usually associated with forest habitats, such as Trachycephalus typhonius, Leptodactylus diptyx, and L. elenae (Uetanabaro et al. 2008), were recorded in plots characterized by a remarkably heterogeneous habitat structure, represented by riparian forest and forest fragments. In contrast, Rhinella spp., Pseudopaludicola sp., and Elachistocleis bicolor inhabit humid and open areas in cerrado (Uetanabaro et 
al. 2008) and were captured in pastures and rice fields, which are homogeneous habitats. Dendropsophus nanus also efficiently uses rice fields. Given the high species abundance, rice agriculture apparently favors anuran species, operating as a substitutive for natural perch habitats. Aquatic species such as Pseudis platensis and $P$. limellum were recorded in those areas with flooded rice fields and drainage channels. These are common representatives from aquatic habitats throughout the Pantanal (Uetanabaro et al. 2008) and have successfully colonized rice fields and neighboring humid areas (Piatti et al. 2010). These findings suggest that population dynamics in the area are affected by local processes related to land use by humans, such as river drainage and forest logging for pasture and agricultural fields. Land management, along with natural flooding, increase availability of humid habitat in the area. The Rio Miranda is the main source of water from which artificial flooding occurs through systems of drainage channels (Piatti et al. 2010, Piatti and Souza 2011). Thus, water is not a limiting resource in this agroecosystem. The presence of full water drainage channels year round creates available humid habitats along the edges of the area and might minimize the impact of seasonal variation on the anuran community; thus, anuran communities in the area may be less sensitive to seasonality of humid areas in environments dominated by rice agriculture.

In the future, expansion of agriculture activity likely will affect biodiversity on a global scale (Dobrovolski et al. 2011). Given that agroecosystem landscapes are expanding, it is critical to recognize these new human-created habitats as a research focus in contemporary ecological studies (Martin et al. 2012). Isolated or interacting factors such as ultraviolet radiation, global climatic change, pollution, diseases, and exotic species are thought to affect amphibian populations (see Silvano and Segalla 2005). However, habitat loss and fragmentation are considered the main causes of amphibian extinction at local and global scales (Becker et al. 2007, 2010). Thus, maintenance of ecosystem integrity and habitat connectivity may be crucial for amphibian conservation strategies (Becker et al. 2010). The Pantanal is one of the largest wetlands of the world; its ecosystem service and biodiversity are under constant threat, given the diverse land-use activities in the region (Alho and Sabino 2011). One of the major priorities for areas under anthropogenic pressure in the Pantanal is the maintenance and protection of key habitats, such as forests and water bodies (Alho and Sabino 2011). The results presented herein emphasize the importance of habitat heterogeneity for anuran species in the Pantanal as a management practice, even in those situations in which anthropic actions are unavoidable such as the agroecosystems.

\section{Acknowledgments}

We thank the Universidade Federal de Mato Grosso do Sul and Conselho Nacional de Desenvolvimento Científico e Tecnológico, CNPq (470148/2006-3) for financial support and Fazenda San Francisco for logistic support. Liliana Piatti and P. L. Filho assisted with fieldwork. Two anonymous reviewers made valuable considerations on the manuscript. Linda Trueb kindly improved the English text. FLS is funded by research grant $\mathrm{CNPq}$ (301071/2011-0).

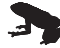

\section{References}

Alho, C. J. R. 2011. Biodiversity of the Pantanal: its magnitude, human occupation, environmental threats and challenges for conservation. Brazilian Journal of Biology 71: 229-232.

Alho, C. J. R. and J. Sabino. 2011. A conservation agenda for the Pantanal's biodiversity. Brazilian Journal of Biology 71: 327-335.

Altieri, M. A. 1999. The ecological role of biodiversity in agroecosystems. Agriculture, Ecosystems \& Environment 74: 19-31. 
Becker, C. G., C. R. Fonseca, C. F. B. Haddad, R. F. Batista, and P. I. Prado. 2007. Habitat split and the global decline of amphibians. Science 318: 1775-1777.

Becker, C. G., C. R. Fonseca, C. F. B. Haddad, and P. I. Prado. 2010. Habitat split as a cause of local population declines of amphibians with aquatic larvae. Conservation Biology 24: 287-294.

Beja, P. and C. Alcazar. 2003. Conservation of Mediterranean temporary ponds under agricultural intensification: an evaluation using amphibians. Biological Conservation 144: 317-326.

Benton, T. G., J. A. Vickery, and J. D. Wilson. 2003. Farmland biodiversity: is habitat heterogeneity the key? Trends in Ecology \& Evolution 18: 182-188.

Colombo, P., A. Kindel, G. Vinciprova, and L. Krause. 2008. Composição e ameaças à conservação dos anfíbios anuros do Parque Estadual de Itapeva, município de Torres, Rio Grande do Sul, Brasil. Biota Neotropica 8: 229-240.

Colwell, R. K. 2009. EstimateS: Statistic estimation of species richness and shared species from samples. Version 8.0. URL: http://viceroy.eeb.uconn.edu/estimates.

Dobrovolski, R., R. D. Loyola, P. D. M. Júnior, and J. A. F. Diniz-Filho. 2011. Agricultural expansion can menace Brazilian protected areas during the $21^{\text {st }}$ century. Natureza \& Conservação 9: 208-213.

Duré, M. I., A. I. Kehr, E. F. Schaefer, and F. Marangoni. 2008. Diversity of amphibians in rice fields from northeastern Argentina. Interciencia 33: 523-527.

Eterovick, P. C. and A. D. M. Ferreira. 2008. Breeding habitat and microhabitat choices by male and female frogs: are there differences between sexes and seasons? Herpetologica 64: 397-405.

Foley, J. A., N. Ramankutty, K. A. Brauman, E. S. Cassidy, J. S. Gerber, M. Johnston, N. D. Mueller, C. O'Connell, D. K. Ray, P. C. West, C. Balzer, E. M. Bennett, S. R. Carpenter, J. Hill, C. Monfreda, S. Polasky, J. Rockström, J. Sheehan, S. Siebert, D. Tilman, and D. P. M. Zaks. 2011. Solutions for a cultivated planet. Nature 478: 337-342.

Gardner, T. A., M. Ribeiro-Júnior, J. Barlow, T. C. ÁvilaPires, M. S. Hoogmoed, and C. A. Peres. 2007. The value of primary, secondary, and plantation forests for a Neotropical herpetofauna. Conservation Biology 21: 775-787.

Guerry, A. D. and M. L. Hunter. 2002. Amphibians distributions in a landscape of forests and agriculture: an examination of landscape composition and configuration. Conservation Biology 16: 745-754.
Hammer, Ø., D. A. T. Harper, and P. D. Ryan. 2001. PAST: Paleontological Statistics software package for education and data analysis. Palaeontologia Electronica 4: 1-9.

Harris, M. B., C. Arcângelo, E. C. T. Pinto, G. Camargo, M. B. R. Neto, and S. M. Silva. 2006. Estimativa da perda de cobertura vegetal original na Bacia do Alto Paraguai e Pantanal brasileiro: ameaças e perspectivas. Natureza \& Conservação 4: 50-56.

Heyer, W. R., M. A. Donnelley, R. W. McDiarmid, L. C. Hayek, and M. S. Foster (eds.). 1994. Measuring and monitoring biological diversity: Standard methods for amphibians. Smithsonian Institution Press.

Hill, J. K. and K. C. Hamer. 2004. Determining impacts of habitat modification on diversity of tropical forest fauna: the importance of spatial scale. Journal of Applied Ecology 41: 744-754.

Jepsen, J. U., C. J. Topping, P. Odderskær, and P. N. Andersen. 2005. Evaluating consequences of land-use strategies on wildlife populations using multiple-species predictive scenarios. Agriculture, Ecosystems \& Environment 105: 581-594.

Joly, P., C. Miaud, A. Lehmann, and O. Grolet. 2001. Habitat matrix effects on pond occupancy in newts. Conservation Biology 15: 239-248.

Junk, W. J., C. N. Cunha, K. M. Watzen, P. Petermann, C. Strüssmann, M. I. Marques, and J. Aids. 2006. Biodiversity and its conservation in the Pantanal of Mato Grosso, Brazil. Aquatic Sciences 68: 278-309.

Krebs, C. J. 1999. Ecological Methodology. Addison-Welsey Educational Publishers, Menlo Park, California.

Machado, I. F. and L. Maltchik. 2010. Can management practices in rice fields contribute to amphibian conservation in southern Brazilian wetlands? Aquatic Conservation 20: 39-46.

Magurran, A. E. 2004. Measuring Biological Diversity. Blackwell Science, Oxford.

Martin, L. J., B. Blossey, and E. Ellis. 2012. Mapping where ecologists work: biases in the global distribution of terrestrial ecological observations. Frontiers in Ecology and the Environment 10: 195-201.

PCBAP. 1997. Projeto Pantanal. Programa Nacional do Meio Ambiente (PNMA). Subcomponente Pantanal. Plano de Conservação da Bacia do Alto Paraguai - PCBAP, v.2, t.3. Diagnóstico dos Meios físico e Biótico. Meio Biótico. MMA/PNMA, Brasília.

Piatti, L. and F. L. Souza. 2011. Diet and resource partitioning among anurans in irrigated rice fields in Pantanal, Brazil. Brazilian Journal of Biology 71: 653-661. 
Piatti L., F. L. Souza, and P. Landgref-Filho. 2010. Anuran assemblage in a rice field agroecosystem in the Pantanal of central Brazil. Journal of Natural History 44: 12151224.

Piha. H., M. Luoto, and J. Merilä. 2007. Amphibian occurrence is influenced by current and historic landscape characteristics. Ecological Applications 17: 2298-2309.

Purrenhage, J. L. and M. D. Bone. 2009. Amphibian community response to variation in habitat structure and competitor density. Herpetologica 65: 14-30.

Ricketts, T. H. 2001. The matrix matters: effective isolation in fragmented landscapes. The American Naturalist 158: 87-99.

Santos, T. G., K. Kopp, M. R. Spies, R. Trevisan, and S. Z. Chechin. 2008. Distribuição temporal e espacial de anuros em área de Pampa, Santa Maria, RS. Iheringia, Série Zoologia 98: 244-253.

Segalla, M. V., U. Caramaschi, C. A. G. Cruz, P. C. A. Garcia, T. Grant, C. F. B. Haddad, and J. Langone. 2012. Brazilian amphibians - List of species. Accessible at http://www.sbherpetologia.org.br. Sociedade Brasileira de Herpetologia. Captured on 27 March 2014.

Silva, R. A., I. A. Martins, and D. C. Rossa-Feres. 2011. Environmental heterogeneity: anuran diversity in homogeneous environments. Zoologia 28: 610-618.

Silvano, D. L. and M. V. Segalla. 2005. Conservação de anfíbios no Brasil. Megadiversidade 1: 79-86.

Souza, F. L., C. P. A. Prado, J. L. M. M. Sugai, V. L. Ferreira, C. Aoki, P. Landgref- Filho, C. Strüssmann, R. W. Ávila, D. J. Rodrigues, N. R. Albuquerque, J. Terra, M. Uetanabaro, A. F. Beda, L. Piatti, R. A. KawashitaRibeiro; M. D. Nunes, G. P. Faggioni, S. D. Demczuk, and S. Duleba. Diversidade de Anfíbios do Estado de Mato Grosso do Sul, Brasil. Iheringia, Série Zoologia. In press.

Ter Braak, C. J. F. 1986. Canonical correspondence analysis: a new eigenvector technique for multivariate direct gradient analysis. Ecology 67: 1167-1179.
Tews, J., U. Brose, V. Grimm, K. Tielbörger, M. C. Wichmann, M. Schwager, and F. Jeltsch. 2004. Animal species diversity driven by habitat heterogeneity/ diversity: the importance of keystone structures. Journal of Biogeography 31: 79-92.

Thomas, G. and D. Clay. 2000. BIODAP - ecological diversity and its measurement. Resource Conservation. Fundy National Park. New Brunswick, Canada. URL: http://nhsbig.inhs.uiuc.edu/populations/bio-dap.zip.

Uetanabaro, M., C. P. A. Prado, D. J. Rodrigues, M. Gordo, and Z. Campos. 2008. Guia de Campo dos Anuros do Pantanal e Planaltos de Entorno. Ed. UFMS/UFMT, Cuiabá, MT.

Vasconcelos, T. S., T. G. Santos, D. C. Rossa-Feres, and C. F. B. Haddad. 2009. Influence of the environmental heterogeneity of breeding ponds anuran assemblages from southeastern Brazil. Canadian Journal of Zoology 87: 699-707.

Vitt, L. J., G. R. Colli, J. P. Caldwell, D. O. Mesquita, A. A. Garda, and F. G. R. França. 2007. Detecting variation in microhabitat use in low-diversity lizard assemblages across small-scale habitat gradients. Journal of Herpetology 41: 654-663.

Wachlevski, M., P. H. C. Souza, K. Kopp, and P. C. Eterovick. 2008. Microhabitat use and feeding habits of Crossodactylus bokermanni Caramaschi and Sazima, 1985 (Anura, Hylodidae) at a site in south-eastern Brazil. Journal of Natural History 42: 1421-1434.

Weibull, A-C., Ö. Östman, and Å. Granqvist. 2003. Species richness in agroecosystems: the effect of landscape, habitat and farm management. Biodiversity and Conservation 12: 1335-1355.

Zamora, J., J. R. Verdu, and E. Galante. 2007. Species richness in Mediterranean agroecosystems: spatial and temporal analysis for biodiversity conservation. Biological Conservation 134: 113-121.

Editor: Tiana Kohlsdorf 